www.jmscr.igmpublication.org

Impact Factor 5.84

Index Copernicus Value: 83.27

ISSN (e)-2347-176x ISSN (p) 2455-0450

crossref DOI:_https://dx.doi.org/10.18535/jmscr/v5i2.98

\title{
Prevalence of Methicilin -Resistant Staphylococcus aureus (MRSA) in Mobile Phone of Healthcare Workers in Baghdad Teaching Hospital
}

\author{
Author \\ Montaha A.AL-Safaar \\ Institute of Medical Technology /Iraq-Baghdad \\ Email:dr.montahabio@yahoo.com
}

\begin{abstract}
All of the tested healthcare workers and patients mobile phones in ICU, Dialysis unit, Operation room and Laboratory hospital in Baghdad teaching hospital were contaminated 100\%: 54\% were Gram positive and 56\% were Gram negative with 9 bacterial isolates included 4 Gram positive bacteria :MRSA S.aureus, CoNS coagulase negative staphylococci, Streptococcus viridans and Bacillus spp ), while Gram negative bacteria: E.coli, Pseudomonas aerogenosa, Klebsiella pneumonia, Salmonella spp, and Proteus spp). The most prevalent organism was found to be MRSA S.aureus from workers, nurses and patients mobile phone at $(10 \%, 8 \% .2 \%)$ respectively except doctor mobile phone were not contaminated by MRSA, while highest bacterial contaminate of Gram negative bacteria Klebsiella spp followed by E.coli in all health workers and patients mobile phones at $(20 \%, 17 \%)$ respectively, while the low percentage rate in Salmonella spp at $3 \%$ in workers and patients mobile phone, in this study $35 \%$ of screened mobile phones of operation room healthcare workers showed bacterial contamination because of their poor health status in addition to the use of intensive equipment like catheters and canola. Samples were cultured and the resulting isolates were identified and subjected to antimicrobial susceptibility tests by standard procedures using disc diffusion method. The resistance rates to commonly used antimicrobials in isolated bacteria from mobile phones varied from 100\% for Methecillin to $14 \%$ for Refamin.
\end{abstract}

Keywords: healthcare workers, mobile phone, nosocomial infection.

\section{INTRODUCTION}

Mobile phones have become an indispensable part of our lives, though they offer plenty of advantage, they are profile breeding grounds for infectious pathogens in communities and hospitals .Mobile devices used in hospitals are of particular interest, as they have been implicated in the spread of nosocomial infections ${ }^{(1,2)}$. Microbial contamination is most commonly found on the mouthpiece, although While indirect contamination from person to person has decreased with the decline in the use of public payphones, cell phones with buttons and keyboards and other personal mobile phones in general has been found to be even more conducive to bacterial contamination $^{(3,4)}$.

Nosocomial infections pose a serious threat to hospitals all over the world. Healthcare workers 
(HCW) play a crucial role in the transmission of bacteria to hospitalized patients. Strict hygiene standards to prevent nosocomial infection are of paramount importance in a hospital setting ${ }^{(5,6,7)}$. Therefore, the presence of a pathogen on a surface at any concentration may be a risk for transmission, and this is reflected in proposed guidelines for microbiological hygiene standards. In recent years, some studies have been conducted on the potential role played by hands and the mobile phones belonging to inpatients in the transmission of important nosocomial pathogens ${ }^{(8,9)}$. The present study seeks to identify the types of bacteria contaminating mobile phones used by health workers (HCWs) and patients at Baghdad teaching hospital; it also tries to investigate the antimicrobial resistance profiles.

\section{Material and Methods Sample Collection}

Across section study was conducted from October 2014 to March 2015, One hundred Samples were collected from mobile phone for healthcare workers and patient from four department included operation room, hospital's laboratory, dialysis unite and intensive care unit (ICU) of Baghdad teaching hospital, Each swab was rotated over the surface of both sides of the tested mobile phone keypad and screen phones. Each cotton ends of these swabs was soaked separately in tubes containing $10 \mathrm{ml}$ of sterile buffered peptone water.

\section{Isolation and identification of bacteria}

Samples from mobile phones were cultured onto Blood, MacConkey, and Chocolate agar then incubated at $37^{\circ} \mathrm{C}$ for 24 hours. The inoculated peptone water were taken a one $\mathrm{ml}$ from each sample was placed in sterile petridish, then $15 \mathrm{ml}$ of melted plate count agar medium was poured over the sample, the agar was thoroughly mixed with the sample and allowed to set and solidity. The plates were then inverted and incubated aerobically at $37^{0} \mathrm{C}$ for 24 hours. Pure cultures were obtained by sub-culturing distinct colonies.
Control samples underwent the same processes. Bacterial isolates were identified using standard techniques as briefly follow.

\section{For Identification of isolates:}

Isolated bacterial agents were identified according to the standard microbiological methods described by Collee et al., (1996) ${ }^{(7)}$. They were identified using Gram's staining, colony morphology and appropriate biochemical tests.

Antibiotic Susceptibility Test (AST):

Antibiotic susceptibility were determined by the agar diffusion technique on Mueller-Hinton agar (Kirby-Bauer NCCLS modified disc diffusion technique) using 9 antibiotic discs (Biotec Lab. UK) corresponding to the drugs most commonly used in the treatment of human and animal infections caused by bacteria; Ampicillin (Amp) (10?g), Tetracycline (Tet) (10?g), Penicillin (Pen) (10IU), Erythromycin (Ery) (5?g), Ampecillin (AM) (30?g), Methecillin (ME), RA(Rifmpin) (5 $\mu \mathrm{g})$. and Chloromphenicol (CL) $(30 \mu \mathrm{g})$.

\section{Results and Discussion}

Out of 127 clinical samples were contaminated by different bacterial isolates, 54\% were Gram positive and $56 \%$ were Gram negative, nine bacterial species isolates were included (MRSA Staphylococcus aureus, CoNS. Streptococcus viridance, Bacillus spp, E.coli, Klebsiella spp, Pseudomonas aerogenosa, Salmonella spp, Proteus spp) in health workers mobile phone at Baghdad teaching hospital .

Workers mobile phone were most contaminated by four gram positive bacteria ((MRSA Staphylococcus aureus, CoNS .Streptococcus viridance, Bacillus spp) by different ratio compared with other, followed by nurses mobile phone ,patients mobile phone at $(19 \%, 10 \%)$ respectively, while Doctors mobile phone at $3 \%$. Fig (1). 


\section{JMSCR Vol||05||Issue||02||Pages 17796-17803||February}

Figure (1); Gram positive bacteria isolated from different healthcare workers and patients.

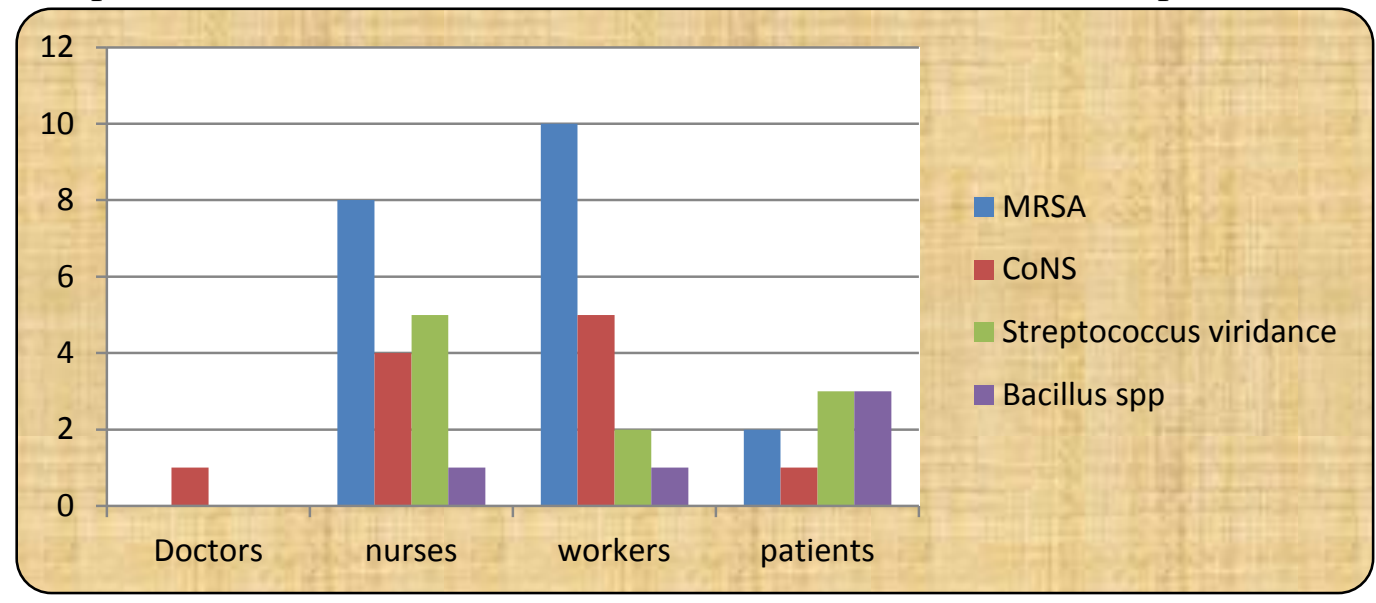

The most prevalent organism was found to be MRSA S.aureus from workers, nurses and patients mobile phone at $(10 \%, 8 \% .2 \%)$ respectively except doctor mobile phone were not contaminated by MRSA, while Streptococcus viridance were isolated from nurses mobile phone at $5 \%$ followed by workers and patients mobile phone at $(2 \%, 3 \%)$.

CoNS (coagulase negative staphylococcus aureus) and Bacillus spp are considered ubiquitous in the environmental are rare to cause disease but perhaps cause nosocomial infection in hospitals and immune compromise patients, from our results, CoNS and Bacillus spp were isolated at high percentage from nurses and workers mobile phone at $(5 \%, 3 \%)(4 \%, 2 \%)$ respectively Fig(1). Mobile phone could be a source of transmission of infections ${ }^{(10)}$.
Some mobile phones were colonized with nonpathogenic bacteria especially CoNS that constitute the normal flora of the skin, CoNS have relatively low virulence but are becoming increasing recognized as the most common cause of nosocomial bacteraemia associated with indulging devices ${ }^{(11,12)}$.

It was apparent from figure (2) that highest bacterial contaminate of Gram negative bacteria Klebsiella spp followed by E.coli in all health workers and patients mobile phones at $(20 \%, 17 \%)$ respectively, while the low percentage rate in Salmonella spp at $3 \%$ in workers and patients mobile phone. The results which we have been get it from this study was important and should be taken seriously because $56 \%$ of mobile phone are contaminated and this coincide with other studies $(13,14,15)$

Figure (2); Gram negative bacteria isolated from different healthcare workers and patients mobile phones

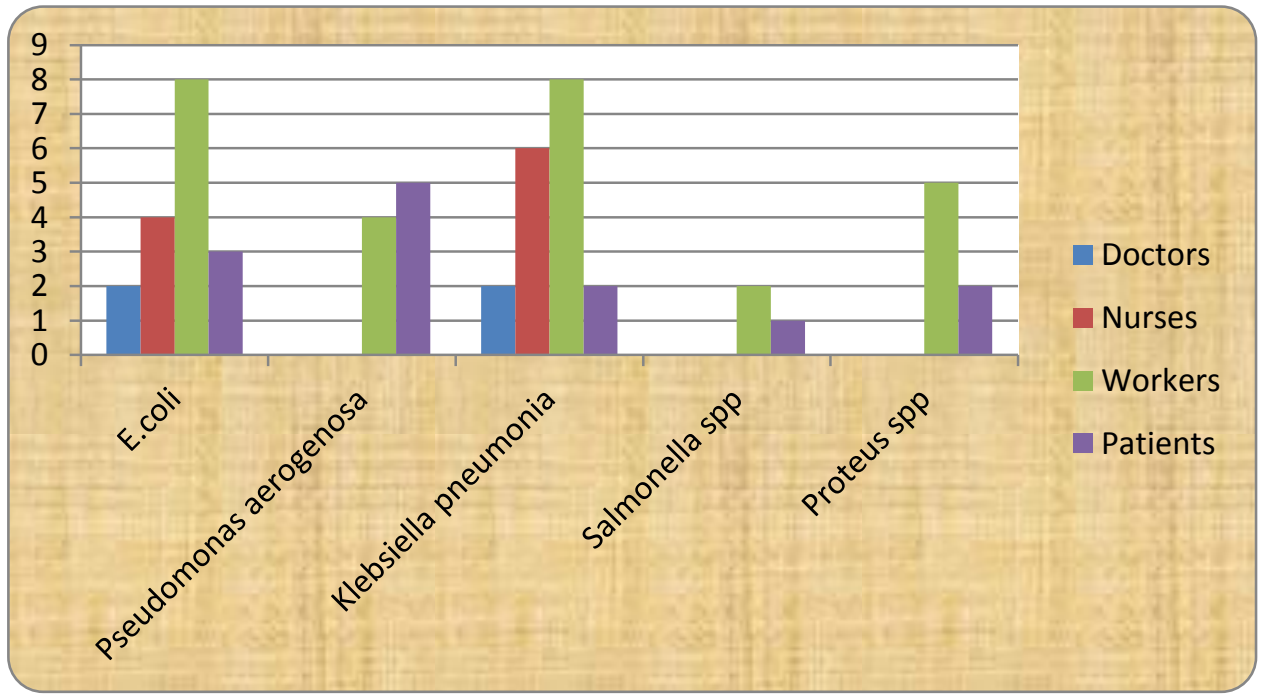




\section{JMSCR VoI||05||Issue||02||Pages 17796-17803||February}

From Figure (2) we notice that the percentage rate of bacterial contamination in mobile phone of health workers and patients in Baghdad teaching hospital, there are nine bacterial isolated included (MRSA S.aureus, CoNS coagulase negative staphylococci, Streptococcus viridans and Bacillus spp, E.coli, Pseudomonas aerogenosa,
Klebsiella pneumonia, Salmonella spp , Proteus spp)., this study showed also that the growth of Gram negative bacteria was high $56 \%$ compared with Gram positive bacteria $44 \%$. The most prevalent organisms among gram positive and negative bacteria MRSA S.aureus, Klebsiella spp, E.coli at $(20 \%, 18 \%, 17 \%, 11 \%)$ respectively .

Figure (3): Total percentage rate of bacterial contamination from mobile phone health workers and patients.

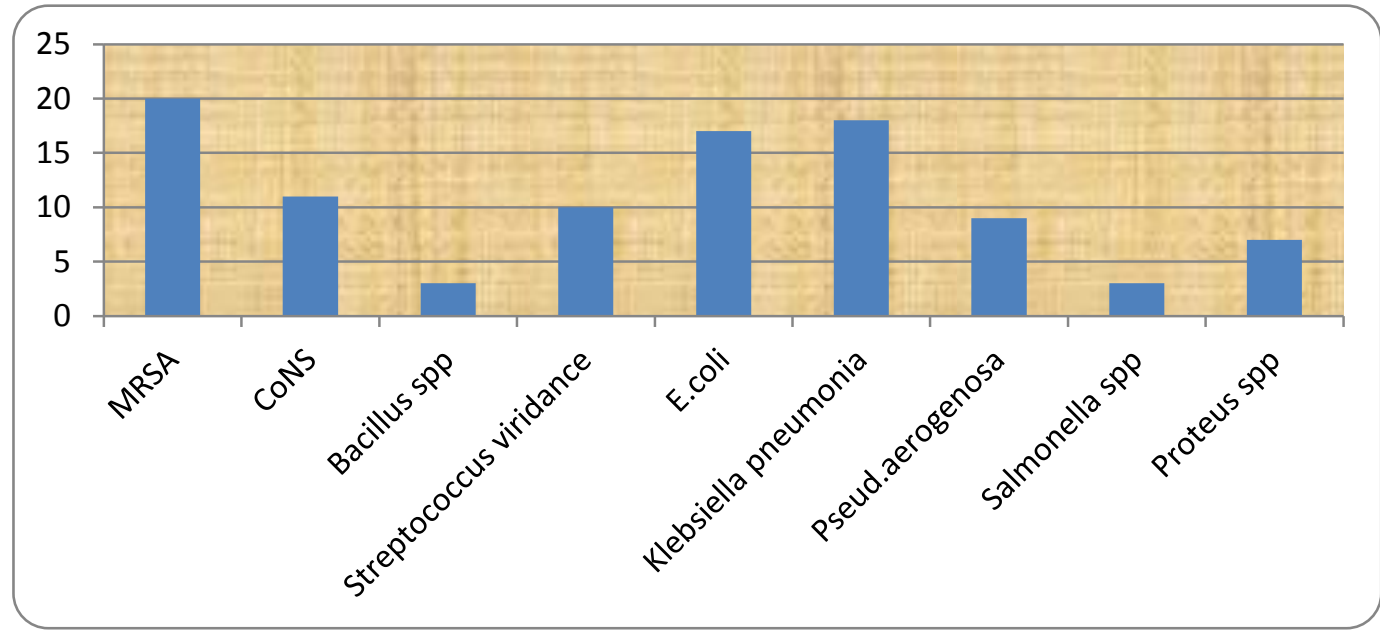

It has been reported that both Gram positive and Gram negative bacteria are able to survive up to months on dry inanimate surfaces with longer persistence's under humid and lower -temperature conditions, factor that may affect the transfer of microorganisms include hand hygiene compliance .t he majority of bacterial species that have been found on phone surfaces are those that are part of the normal flora of the skin and body, due to the constant contact with the hands and face. The most common normal flora of the skin species being Staphylococcus epidermidis and Corynebacteria $^{(16,17,18)}$. In addition, bacteria found in the mouth and the upper respiratory tract can also spread through aerosols and droplets that are released while breathing or talking into the mouthpiece ${ }^{(19,20)}$. Many species are resistant to desiccation and can persist on phone surfaces for weeks, with Gram-negative bacteria usually persisting longer than their gram-positive counterparts ${ }^{(21)}$. Despite this, actual colonization and growth of bacteria is rare due to the general lack of nutrients and moisture on the plastic and glass surfaces of phones. 
Figure (4): Percentage rate of bacterial contamination from healthcare workers and patients mobile phones of different place in Baghdad teaching hospital .

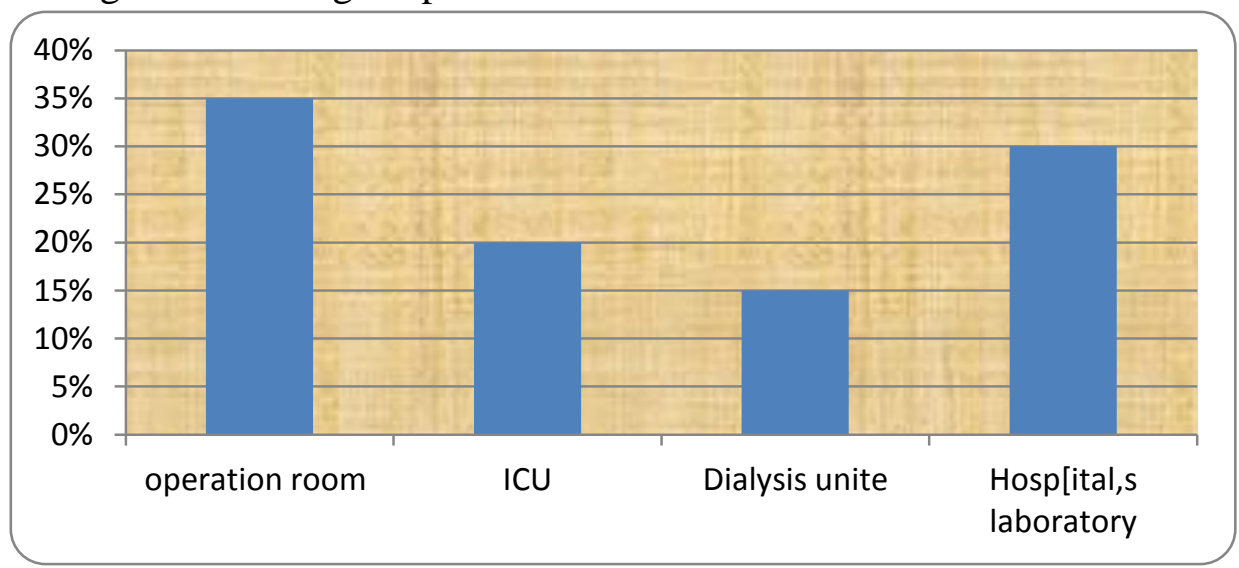

There were many reason for the highest contamination of operation room included the inanimate environment in operation room (e.g., walls, tables, floors and equipment surfaces) has been considered a potential source of pathogens that may cause surgical site infections, despite standard environmental cleaning, these pathogens can then be transmitted to the hands of personnel and then to patients and may result infection outbreaks ${ }^{(23)}$.

The present finding also support authors studies which concluded that there was a correlation between isolated bacterium found on health care workers' hands and their respective mobile devices, demonstrating the cross-contamination potential of mobile phones in the hospital environment. Furthermore, there is also the risk of further transmitting nosocomial pathogens outside of the hospital if health care workers use the same cell phone for personal use.

Also contamination may include infectious organisms within the healthcare sitting, special concern should be given to contact with blood and its components, or body fluids consisting to feces ,urine ,vomits , nasal secretions ...etc. the spread of such biological material and organisms can produce illness, infection or death especially in susceptible individuals, it should be realized that performing/conducting certain procedures /operations within healthcare /and related settings can generate especially large amounts of contamination $^{(24,25)}$.
Susceptibility of bacterial isolates to 9 different antibiotics.

This study revealed that many resistant strains of different isolates were prevalent in the mobile phones that further emphasize the public health significance of the notes and clearly indicates a marked resistance to the commonly used antibiotics For example, isolates of various bacterial species recorded high rates of resistance collectively as MRS S.aureus was showed resistance to Methicillin, tetracycline, penicillin at $100 \%$ while resistance absent for other isolates Fig (5). And high resistance for tetracycline were observed in Streptococcus viridance at $75 \%$.

Gram negative bacteria isolates such as E.coli, Pseudomonas aerogenosa, Klebsiella spp and Salmonella spp showed vresistance to ampicillin at $(71 \%, 55 \%, 67 \%, 50 \%)$ respectively. While Salm-onella spp showed high resistance to tetracycline at $75 \%$ compared with other gram negative bacteria.

The emergency of resistance to antibiotics commonly used in bacterial isolates contaminated mobile phone which is widely recognized as responsible for many community infections for healthy persons such as MRSA S.aureus, Klebsiella pneumonia. Pseudomonas aerogenosa, Streptococcus viridians it making this mobile contagious tool (fomite) play important role in spreading and transported Drug -resistance bacteria in community which were difficult to treat. 


\section{JMSCR Vol||05||Issue||02||Pages 17796-17803||February}

Amaximum percentage of resistance $100 \%$ was observed by MRSA S.aureus isolate against Methicillin, tetracycline, penicillin, this may be due to this belonging to the same group (betalactam group) and their similarity in action on the cell wall ${ }^{(20)}$.

Figure (5): Antibiotic Resistance Patterns of bacterial isolates from mobiles phone healthcare workers and patients to 9 different antibiotics.

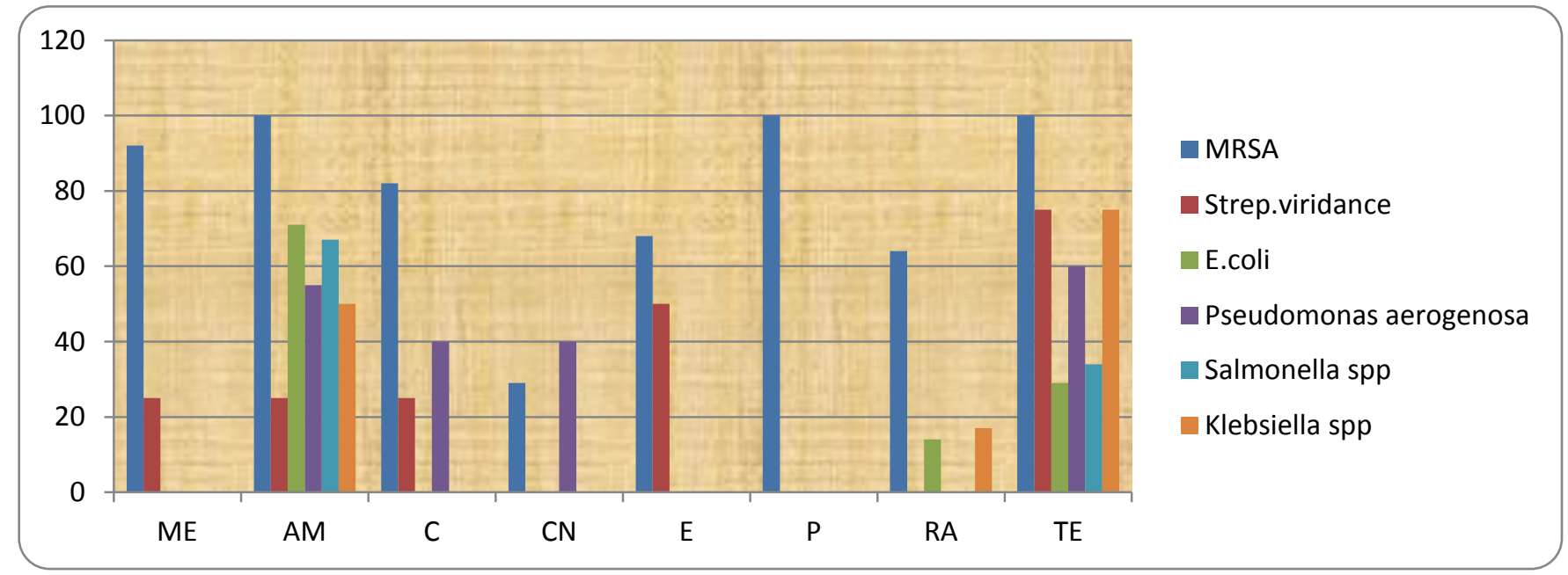

AM: Ampecillin ME: Methecillin C:Cholormphenicol CN: Gentamycin E:Erethromycin P:Pencillin RA: Refamin TE; Tetracycline

\section{References}

1. Muzslay M, Lee E, Alder S, et al. Key pad mobile phones are associated with a significant increased risk of microbial contamination compared to touch screen phones. Journal of Infection Prevention 2013; 14(2): 65-68.

2. Khan S, Shaikh AA. Mobile phones: reservoir of infectious diseases in university premises. NED University Journal of Research 2012; 9(1): 35-43.

3. Ilusanya OAF, Adesanya OO, Adesemowo A, Amushan NA. Personal Hygiene and Microbial Contamination of Mobile Phones of Food Vendors in Ago-Iwoye Town, Ogun State, Nigeria. Pakistan Journal of Nutrition. 2012;11:276-27.

4. Edem EN, Onwuezobe IA, Ochang EA, Etok CA, James IS. Antibiogram of bacterial isolates from the anterior nares and hands of health care workers in University of Uyo Teaching Hospital (UUTH) Uyo, Akwalbom State, Nigeria. Journal of Bacteriol Parasitol 2013; 4(2): 1-5..
5. Razine R, Azzouzi A, Barkat A, et al. Prevalence of hospital-acquired infections in the university medical center of Rabat, Morocco. International Archives of Medicine 2012; 5(26): 1-8.

6. Endalafer N, Gebre-Selassie S, Kotiso B. Nosocomial bacterial infections in a tertiary hospital in Ethiopia. Journal of Infection Prevention 2010; 11(6): 17571774.

7. Colle.G.,Fraser .A.G.,Marmion .B.P.,and Simmons A.,(1996).Makie and McCarthey practical microbiology ,14ed ed .Churchill Livingeston .New York.U.S.A.

8. Mikyas D, Sileshi L. The prevalence of nosocomial infections and associated risk factors in pediatric patients in Tikur Anbessa Hospital. Ethiopian Journal of Pediatrics and Child Health 2009;5(5):14.

9. Tesfahunegn Z, Asrat D, Woldeamanuel Y, Estifanos K. Bacteriology of surgical site and catheter related urinary tract infections among patients admitted in Mekelle 
Hospital, Mekelle, Tigray, Ethiopia. Ethiopian Medical Journal 2009; 47(2): 117-127.

10. Borkow G, Monk A. Fighting nosocomial infections with biocidal non-intrusive hard and soft surfaces. World Journal of Clinical Infectious Disease 2012; 2(4): 7790. http://dx.doi. org/10.5495/wjcid.v2.i4.77.

11. Nyasulu P, Murray J, Perovic O, Koornhof H. Antimicrobial resistance surveillance among nosocomial pathogens in South Africa: Systematic review of published literature. Journal of Experimental \& Clinical Medicine 2012; 4(1): 8e13.

12. Jain A, Singh K. Recent advances in the management of nosocomial infections. Journal of Medical Education and Research 2007; 9(1): 1-8.

13. Eze JC, Ekpo EU, Nzotta CC, Asogwa NC, Egbe NO. X-ray equipments and accessories as possible vectors of nosocomial bacteria in Anambra State, Nigeria. Journal of Association of Radiographers of Nigeria 2012; 26: 18-27.

14. Otter J, Yezli S, French G. The role played by contaminated surfaces in the transmission of nosocomial pathogens. Infect Control Hospital Epidemiology 2011; 32(7): 687-699. http:// dx.doi.org/10.1086/660363

15. Annand JW, Bajaj N, Sheth A, Burgess J, Brooke JS. Potential pathogens and effective disinfectants on public telephones at a large urban United States university. Journal of environmental health. 2009;71:24.

16. Nikolic M, Arandjelovic M, Stankovic A, Krivokapic L. Bacterial contamination of mobile phones used in hospitals. HEALTHMED. 2011;5:1254-1259.

17. Lee YJ, Yoo CG, Lee CT, Chung HS, Kim YW, Han SK, Yim, JJ. Contamination rates between smart cell phones and nonsmart cell phones of healthcare workers.
Journal of Hospital Medicine. 2013;8:144147. doi: 10.1002/jhm.2011.

18. Tunç K, Olgun U. Microbiology of public telephones. The Journal of infection. 2006;53:140-143.

19. Abdollahi A, Mahfouzi S. Bacterial contamination of Hospital Telephones. Pakistan Journal of Medical Sciences. 2010;26(3):747-750.

20. Smith SI, Opere B, Goodluck HT, et al. Antibiotic susceptibility pattern of Staphylococcus species isolated from telephone receivers. Singapore medical journal. 2009;50:208.

21. Kramer A, Schwebke I, Kampf G. How long do nosocomial pathogens persist on inanimate surfaces? A systematic review. BMC infectious diseases. 2006;6:130-130.

22. Borer A, Schlaeffer F, Gilad J, et al. Cell phones and Acinetobacter transmission. Emerging infectious diseases. 2005;11:1160-1161.

23. Visvanathan A, Gibb AP, Brady RRW. Increasing Clinical Presence of Mobile Communication Technology: Avoiding the Pitfalls. Telemedicine journal and ehealth: the official journal of the American Telemedicine Association. 2011;17:656-661.

24. Brady RRW, Verran J, Damani NN, Gibb AP. Review of mobile communication devices as potential reservoirs of nosocomial pathogens. The Journal of hospital infection. 2009;71:295-300.

25. Yusha'u M. Isolation of bacteria and fungi from personal and public mobile cellphones. International Journal of Biomedical and Health Sciences. 2010;6;98-102.

26. Peleg AY, Seifert H, Paterson DL. Acinetobacter baumannii: emergence of a successful pathogen. Clinical microbeology reviews. 2008;21:538-582.

27. Hedin G (1993), "Staphylococcus epidermidis - hospital epidemiology and the detection of methicillin resistance", 
Scandinavian Journal of Infectious Diseases Supplementum (Oslo Norway: Scandinavian University Press)

28. Otto M. Staphylococcus epidermidis - the 'accidental' pathogen. Nature Reviews Microbiology. 2009; 7:555-567.

29. Holmes JW, Williams MD. Methicillinresistant staphylococcus aureus screening and eradication in the surgical intensive care unit: Is it worth it? Am J Surg. 2010;200:827-831.

30. Jeske H, Tiefenthaler W, Hohlrieder M, Hinterberger G, Benzer A. Bacterial contamination of anaesthetists' hands by personal mobile phone and fixed phone use in the operating theatre. Anaesthesia. 2007;62:904.

31. Ulger F, Esen S, Dilek A, Yanik K, Gunaydin M, Leblebicioglu H. Are we aware how contaminated our mobile phones with nosocomial pathogens? Annals of clinical microbiology and antimicrobials. 2009;8:7-7. 